\title{
JEKK
}

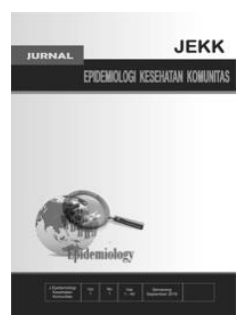

\section{Hubungan Kelengkapan Kunjungan ANC, Umur Ibu Hamil dan Konsumsi Fe $<90$ Tablet dengan Kematian Neonatal}

\author{
Kukuh Purwo Saputro ${ }^{*}$, Mexitalia Setiawati* ${ }^{* *}$ Suhartono $^{* * *}$ Dwi Sutiningsih ${ }^{* * *}$ \\ *Magister Epidemiologi, Sekolah Pascasarjana, Universitas Diponegoro, Semarang. \\ ** Fakultas Kedokteran, Universitas Diponegoro, Semarang \\ *** Fakultas Kesehatan Masyarakat, Universitas Diponegoro, Semarang
}

\begin{abstract}
Background: Neonatal deaths are those that occur in the neonatal period when the baby is born up to 28 days (0-28 days). Neonatal mortality contributes to $56 \%$ of infant deaths due to complications such as BBLR, asphyxia, and infections that should be prevented by taking into account the condition of the mother before and during pregnancy because it will determine the condition of the baby being born. This study aimed to determine maternal factors associated with neonatal mortality. Methods: The design of an analytic observational study using a case-control. The population of the study was infants born in Banjarnegara District in 2018. The sample of the study was 65 cases and 65 controls taken by simple random sampling. The data were analyzed univariate and bivariate.

Result: The results showed a significant relationship between the completeness of the ANC visit ( $\mathrm{p}$ $=0.029 ; \mathrm{OR}=3.6(95 \% \mathrm{CI}=1.222-10.595))$ and the consumption of $\mathrm{Fe}<90$ tablets $(\mathrm{p}=0.0001$; $\mathrm{OR}=4,1(95 \% \mathrm{CI}=1,942-8,816))$ with neonatal mortality. There was no relationship between the age of pregnant women $<20$ years old and $>35$ years old with neonatal mortality.

Conclusion: The conclusion of this study is the variables that are statistically related to neonatal mortality are completeness of ANC visit and consumption of $\mathrm{Fe}<90$ tablets.
\end{abstract}

Keywords: Neonatal; Antenatal Care; Age of pregnant; Fe.

*Penulis korespondensi, kukuhpurwo7@gmail.com 


\section{Pendahuluan}

Kematian neonatal merupakan kematian yang terjadi pada periode neonatal dimulai sejak bayi lahir sampai dengan 28 hari (0-28 hari). ${ }^{1}$ Perhatian terhadap upaya penurunan AKN menjadi penting karena kematian neonatal memberi kontribusi 59\% kematian bayi. Hasil Survei Demografi dan Kesehatan Indonesia (SDKI) tahun 2012, angka kematian neonatal tahun 2012 sebesar 19 per 1.000 kelahiran hidup. ${ }^{2}$ Salah satu target Sustainable Development Goals (SDGs) 2015-2030 dalam goals 3 adalah mengakhiri kematian bayi dan balita yang dapat dicegah, yaitu dengan menurunkan angka kematian neonatal hingga 12 per 1.000 kelahiran hidup. $^{3}$

Hasil Riskesdas (2007) menunjukan penyebab kematian neonatal terbanyak adalah asfiksia, berat bayi lahir rendah (BBLR) dan infeksi. ${ }^{4}$ BBLR masih menjadi masalah di Kabupaten Banjarnegara dengan jumlah kasus $7,1 \%$ dan merupakan yang tertinggi di Provinsi Jawa Tengah. BBLR merupakan penyebab 43,67\% kematian neonatal di Kabupaten Banjarnegara. ${ }^{1}$ Kasus komplikasi pada bayi baru lahir dapat dicegah salah satunya dengan cara meningkatkan pelayanan kesehatan ibu hamil. Ibu hamil dianjurkan melakukan antenatal care (ANC) yang berkualitas paling sedikit 4 kali selama masa kehamilan. Cakupan pelayanan K4 (jumlah ibu hamil yang memperoleh pelayanan antenatal sesuai standar paling sedikit 4 kali, dibanding jumlah sasaran ibu hamil di suatu wilayah kerja pada kurun waktu satu tahun) sebesar 85,8\% tahun 2015 dan $87,4 \%$ tahun 2016 dari target $100 \%$. ANC merupakan program terencana berupa observasi, edukasi dan penanganan medik pada ibu hamil, dengan tujuan menjaga agar ibu sehat selama kehamilan, persalinan, dan nifas serta mengusahakan bayi yang dilahirkan sehat. ${ }^{6}$ Proses kehamilan dan persalinan yang aman dan memuaskan memantau kemungkinan adanya risiko-risiko kehamilan merencanakan penatalaksanaan yang optimal terhadap kehamilan risiko tinggi dan menurunkan morbilitas dan mortalitas ibu dan janin.

Usia 21-35 tahun adalah masa dimana ibu hamil memiliki risiko kesehatan paling rendah atau disebut sebagai waktu ideal untuk hamil dan melahirkan. Umur ibu berpengaruh terhadap faktor biologis yang menyebabkan terjadinya komplikasi selama masa kehamilan dan persalinan yang berdampak pada kematian ibu dan bayi. Alat reproduksi saat umur ibu kurang 20 tahun belum matang, rahim dan panggul belum tumbuh mencapai ukuran dewasa, pada proses persalinan bisa memakan waktu lama. Usia lebih 35 tahun sel-sel dalam tubuh ibu mulai terjadi regresi, kesehatan ibu mulai menurun dan jalan lahir kaku. ${ }^{5}$ Kabupaten Banjarnegara memiliki kasus pernikahan dini yang cukup tinggi, data dari DPPKB P3A dari total pernikahan tahun 2017 $30 \%$ merupakan pernikahan yang dilakukan oleh pasangan dibawah umur. ${ }^{7}$

Ibu hamil juga rentan mengalami anemia karena defisiensi zat besi. Anemia pada saat hamil dapat mengakibatkan efek yang buruk bagi ibu maupun janin. Anemia dapat mengurangi suplay oksigen pada metabolisme ibu karena kadar hemoglobin untuk mengikat oksigen yang dapat mengakibatkan efek tidak langsung kepada ibu dan janin antara lain terjadi abortus, selain itu ibu lebih rentan terhadap infeksi dan kemungkinan bayi lahir prematur. Ibu hamil disarankan untuk mengonsumsi minimal 90 tablet Fe selama kehamilan. Cakupan ibu hamil yang mendapat 90 tablet Fe di Jawa Tengah tahun 2016 mengalami penurunan dari tahun sebelumnya sebesar $92,13 \%$ menjadi $88,12 \% .^{8}$

Berdasarkan latar belakang diatas peneliti ingin melakukan penelitian tentang hubungan kelengkapan antenatal care, usia ibu saat hamil dan konsumsi $\mathrm{Fe}<90$ tablet dengan kematian neonatal yang ada di Kabupaten Banjarnegara. Tujuan penelitian ini adalah untuk mengetahui hubungan kelengkapan antenatal care, usia ibu saat hamil dan konsumsi Fe $<90$ tablet pada ibu hamil dengan kematian neonatal yang ada di Kabupaten Banjarnegara.

\section{Metode}

Jenis penelitian yang dilakukan adalah studi observasional analitik dengan desain studi kasus kontrol. Variabel terikat pada penelitian ini adalah kejadian kematian neonatal, variabel 
bebas dalam penelitian ini kelengkapan kunjungan antenatal, usia ibu hamil dan jumlah konsumsi tablet Fe selama kehamilan.

Populasi target dalam penelitian ini adalah semua bayi yang ada di wilayah Dinas Kesehatan Kabupaten Banjarnegara. Populasi studi kasus pada penelitian ini adalah semua kematian bayi yang tercatat di puskesmas wilayah Dinas Kesehatan Kabupaten Banjarnegara tahun 2018. Populasi studi kontrol dalam penelitian ini adalah Populasi kontrol adalah semua bayi lahir hidup yang tercatat di puskesmas wilayah Dinas Kesehatan kabupaten Banjarnegara tahun 2018.

Sampel dari penelitian ini sebesar 130 responden yang dipilih dengan simple random sampling, terdiri dari 65 responden kelompok kasus dan 65 responden kelompok kontrol. Sampel dari kelompok kasus dipilih dari 95 kasus kematian neonatal yang memenuhi kriteria inklusi (Bayi lahir hidup dan kemudian meninggal pada periode neonatal yang dilaporkan ke Dinkes, bertempat tinggal di wilayah penelitian dan bersedia mengikuti penelitian dengan mengisi informed consent) dan kriteria eksklusi (ibu melahirkan bayi kembar). Sampel kelompok kontrol dipilih dengan cara melakukan matching lokasi, jenis kelamin dan tanggal lahir yang berdekatan dengan kelompok kasus.

Penelitian dilakukan di 25 Puskesmas wilayah Kabupaten Banjarnegara. Pengambilan data bersumber dari data Puskesmas dan hasil wawancara dengan kuesioner. Waktu pelaksanaan penelitian pada bulan JanuariFebruari tahun 2019. Pengolahan dan analisa data dilakukan dengan program SPSS meliputi analisis univariat dan bivariat dengan uji chi square. Penelitian ini sudah mendapatkan ethical clearance dari Komisi Etik Penelitian Kesehatan (KEPK) Fakultas Kedokteran Universitas Diponegoro Semarang.

\section{Hasil}

Jumlah responden penelitian sebanyak 130 responden, terdiri 65 responden kelompok kasus dengan kematian neonatal dan 65 responden kelompok kontrol dengan bayi yang bisa bertahan melewati masa neonatal.
Tabel 1. Karakteristik Subyek Penelitian

\begin{tabular}{|c|c|c|c|c|}
\hline \multirow[t]{2}{*}{ Variabel } & \multicolumn{2}{|c|}{ Kasus } & \multicolumn{2}{|c|}{ Kontrol } \\
\hline & $\mathbf{n}$ & $\%$ & $\mathbf{n}$ & $\%$ \\
\hline \multicolumn{5}{|c|}{ Kelengkapan kunjungan ANC } \\
\hline Tidak & 15 & 23,1 & 5 & 7,7 \\
\hline lengkap & & & & \\
\hline Lengkap & 50 & 76,9 & 60 & 92,3 \\
\hline \multicolumn{5}{|c|}{ Jumlah konsumsi tablet Fe } \\
\hline$<90$ tablet & 36 & 55,4 & 15 & 23,1 \\
\hline$\geq 90$ tablet & 29 & 44,6 & 50 & 76,9 \\
\hline \multicolumn{5}{|c|}{ Usia ibu hamil } \\
\hline$<20$ tahun & 14 & 21,5 & 7 & 10,8 \\
\hline$>35$ tahun & 11 & 16,9 & 5 & 7,7 \\
\hline 20-35 tahun & 40 & 61,6 & 53 & 81,5 \\
\hline
\end{tabular}

Tabel 1 menunjukkan bahwa responden dengan antenatal care tidak lengkap ( $<4$ kali) lebih banyak pada kelompok kasus $(23,1 \%)$ dibanding kelompok kontrol $(7,7 \%)$. Responden dengan konsumsi $\mathrm{Fe}<90$ tablet lebih banyak pada kelompok kasus $(55,4 \%)$ dibanding kelompok kontrol (23,1\%). Responden dengan usia kehamilan $<20$ tahun lebih banyak pada kelompok kasus $(21,5 \%)$ dibanding kelompok kontrol $(10,8 \%)$ dan responden dengan usia kehamilan $>35$ tahun lebih banyak pada kelompok kasus $(16,9 \%)$ dibanding kelompok kontrol $(7,7 \%)$.

Analisis bivariat dilakukan dengan menggunakan uji chi-square. Pengambilan keputusan berdasarkan nilai $\mathrm{p}<0,05$ maka dinyatakan memiliki hubungan yang bermakna antar variabel.

Tabel 2. Hasil Analisis Bivariat terhadap Kejadian Kematian Neonatal

\begin{tabular}{lccl}
\hline \multicolumn{1}{c}{ Variaibel } & $\boldsymbol{p}$ & OR & $\mathbf{9 5 \%}$ CI \\
\hline $\begin{array}{l}\text { Kelengkapan } \\
\text { kunjungan ANC }\end{array}$ & 0,029 & 3,600 & $1,223-$ \\
$\begin{array}{l}\text { Usia ibu hamil } \\
<20 \text { tahun }\end{array}$ & & & 10,595 \\
& 0,086 & 2,650 & $0,979-$ \\
>35 tahun & 0,249 & 2,082 & $0,741-$ \\
& & & 5,848 \\
Konsumsi tablet Fe & 0,0001 & 4,138 & $1,942-$ \\
& & & 8,816 \\
\hline
\end{tabular}


Pada hasil analisis bivariat variabel yang memiliki hubungan signifikan secara statistik dengan kejadian kematian neonatal adalah kelengkapan kunjungan ANC $p=0,029$; $\mathrm{OR}=3,6(95 \% \mathrm{CI}=1,223-10,595)$ dan konsumsi tablet $\mathrm{Fe} p=0,0001 ; \mathrm{OR}=4,1 \quad(95 \% \mathrm{CI}=1,942$ 8,816).

\section{Pembahasan}

\section{Kelengkapan Kunjungan Antenatal Care}

Ibu hamil dengan kunjungan antenatal tidak lengkap memiliki risiko 3,6 kali lebih besar untuk mengalami kejadian kematian neonatal dibanding ibu dengan kunjungan antenatal lengkap sesuai standar. Tujuan utama antenatal care adalah untuk memfasilitasi ibu hamil, mendeteksi komplikasi-komplikasi yang dapat mengancam jiwa, mempersiapkan kelahiran dan memberikan pendidikan. Antenatal care sebaiknya segera dilakukan setelah ibu merasa dirinya hamil. Pemeriksaan ini juga untuk memastikan bahwa semua masalah kesehatan yang timbul akan segera dirawat secara dini agar ibu hamil dapat melalui masa kehamilan, persalinan dan nifas dengan baik dan selamat serta menghasilkan bayi yang sehat. Pada kunjungan ANC petugas kesehatan dapat memantau kemajuan kehamilan untuk memastikan kesehatan ibu dan tumbuh kembang bayi, meningkatkan dan mempertahankan kesehatan fisik, mental dan sosial dari ibu, perencanaan antisipasi dan persiapan dini untuk melakukan rujukan jika terjadi komplikasi, serta mempersiapkan persalinan yang bersih dan aman. Asuhan antenatal yang teratur bisa mendeteksi dini penyulit tumbuh kembang janin selama hamil seperti Intra Uterine Growth Retardation (IUGR), Small for Gestasional Age (SGA), Large for Gestasional Age (LGA), maupun Intra Uterine Fetal Distress /IUFD. ${ }^{9}$

\section{Konsumsi Tablet Fe}

Pada variabel konsumsi tablet $\mathrm{Fe}$, ibu hamil dengan konsumsi $\mathrm{Fe}<90$ tablet memiliki risiko 4,1 kali lebih besar untuk mengalami kejadian kematian neonatal dibanding ibu dengan konsumsi $\mathrm{Fe} \geq 90$ tablet. Hasil penelitian ini konsisten dengan hasil penelitian
Fatimatasari $p=0,036 ; \quad \mathrm{OR}=2,09 \quad(95 \% \quad \mathrm{CI}=$ 1,044-4,194) yang menyatakan ada hubungan antara kepatuhan konsumsi tablet $\mathrm{Fe}$ dengan kejadian bayi berat lahir rendah. ${ }^{10}$ Ibu hamil merupakan salah satu kelompok rawan kekurangan gizi, karena terjadi peningkatan kebutuhan gizi untuk memenuhi kebutuhan ibu dan janin yang dikandung. Salah satu masalah gizi yang banyak terjadi pada ibu hamil adalah anemia. ${ }^{11}$ Anemia dapat mengurangi suplay oksigen pada metabolisme ibu karena kadar hemoglobin untuk mengikat oksigen yang dapat mengakibatkan efek tidak langsung kepada ibu dan janin antara lain terjadi abortus, selain itu ibu lebih rentan terhadap infeksi dan kemungkinan bayi lahir prematur. ${ }^{12}$ Untuk mencegah kejadian tersebut maka kebutuhan ibu dan janin akan tablet besi harus dipenuhi. Zat besi adalah mineral yang dibutuhkan untuk membentuk sel darah merah (hemoglobin). Selain itu, mineral ini juga berperan sebagai komponen untuk membentuk mioglobin (protein yang membawa oksigen ke otot) dan kolagen (protein yang terdapat di tulang, tulang rawan, dan jaringan penyambung), zat besi juga berfungsi dalam sistem pertahanan tubuh. ${ }^{13}$

\section{Usia Ibu saat Hamil}

Pada variabel usia ibu hamil $<20$ tahun tidak berhubungan secara signifikan dengan kejadian kematian neonatal $(p=0,086)$, begitu juga usia ibu hamil >35 tahun tidak berhubungan secara signifikan dengan kejadian kematian neonatal $(p=0,249)$. Hasil penelitian ini sejalan dengan hasil penelitian Rofiqoch $(p=0,407)$ dan Mahmudah $(p=0,503)$ bahwa tidak terdapat hubungan yang bermakna antara usia ibu dengan kematian neonatal. ${ }^{14,15}$ Usia ibu hamil tidak berhubungan dengan kematian neonatal bisa juga disebabkan karena ibu hamil usia <20 tahun dan >35 tahun rutin memeriksakan kehamilan di fasilitas kesehatan mendapat informasi kehamilan dari bidan atau dokter saat konsultasi, sehingga risiko untuk mengalami kejadian kematian neonatal dapat diminimalisir. ${ }^{15}$ Perkembangan teknologi informasi yang begitu cepat juga berpengaruh terhadap semakin mudahnya ibu hamil dalam 
memperoleh informasi terkait kesehatan seputar kehamilan dan persalinan.

\section{Kesimpulan}

Ada hubungan yang bermakna antara kelengkapan kunjungan antenatal dan konsumsi tablet $\mathrm{Fe}$ pada masa kehamilan dengan kejadian kematian neonatal. Ibu hamil sebaiknya memeriksakan kehamilan yang berkualitas sesuai dengan standar yaitu minimal 4 kali selama kehamilan dan mengkonsumsi tablet Fe sesuai anjuran petugas kesehatan untuk meminimalisir terjadinya anemia pada kehamilan yang akan berakibat buruk bagi ibu dan janin.

\section{Ucapan Terimakasih}

Terima kasih pada semua pihak yang telah membantu khususnya kepada Dinas Kesehatan Kabupaten Banjarnegara dan responden yang bersedia turut serta dalam penelitian ini.

\section{Daftar Pustaka}

1. Dinas Kesehatan Kabupaten Banjarnegara. 2017. Profil Kesehatan Tahun 2016. Banjarnegara.

2. Kementerian Kesehatan. 2017. Profil Kesehatan Indonesia 2016. Jakarta: Pusat Data dan Informasi.

3. Ermalena. 2017. Indikator Kesehatan SDGs di Indonesia. Materi Disampaikan dalam Diskusi Panel "Pengendalian Tembakau dan Tujuan Pembangunan Indonesia” The 4th ICTOH, 15 Mei 2017.

4. Kementerian Kesehatan. 2008. Riset Kesehatan Dasar (Riskesdas 2007). Jakarta: Badan Penelitian dan Pengembangan Kesehatan Kementerian Kesehatan RI.

5. Padila. 2014. Keperawatan Maternitas. Yogyakarta: Nuha Medika.
6. Mufdilah. 2009. ANC Pemeriksaan Kehamilan Fokus. Jakarta : Mulia Medika.

7. Badan Pusat Statistik. 2016. Kemajuan yang Tertunda: Analisis Data Perkawinan Usia Anak di Indonesia. Jakarta: Badan Pusat Statistik.

8. Dinas Kesehatan Provinsi Jawa Tengah. 2017. Profil Kesehatan Tahun 2016.

9. Hardiani RS, Purwanti A. 2012. Motivasi dan kepatuhan kunjungan ANC pada ibu hamil trimester III. Jurnal Keperawatan 3 (2).

10. Fatimatasari, Hamam H, Nur IR. 2013. Kepatuhan Mengonsumsi Tablet $\mathrm{Fe}$ Selama Hamil Berhubungan dengan Kejadian Bayi Berat Lahir Rendah (BBLR) di Kabupaten Bantul. Jurnal Ners dan Kebidanan Indonesia. 1 (3).

11. Fatimah H. 2011. Pola Konsumsi dan Kadar Hemoglobin pada Ibu Hamil di Kabupaten Maros Sulawesi Selatan. Makara Kesehatan. 15 (1): 31-36.

12. Saifuddin. 2006. Pelayanan Kesehatan Maternal \& Neonatal. Jakarta: Yayasan Bina Pustaka Sarwono Prawirohardjo.

13. Sulistyoningtyas I. 2012. Pemberian Zat Besi (Fe) dalam Kehamilan. Majalah Ilmiah Sultan Agung. 50 (128).

14. Rofiqoch I, Jusuf SE, Dinan S, Baratakoesoema. 2016. Hubungan Umur Ibu, Paritas dan Penolong Persalinan dengan Kematian Neonatal di Wilayah Kerja Puskesmas Kabupaten Banjarnegara Tahun 2013. Jurnal Kesehatan Reproduksi. .3 (1): 60-68.

15. Mahmudah U, Widya HC, Anik SW. 2011. Faktor Ibu dan Bayi yang Berhubungan dengan Kejadian Kematian Perinatal. Jurnal Kesehatan Masyarakat. Kemas 7 (1): .41-50. 